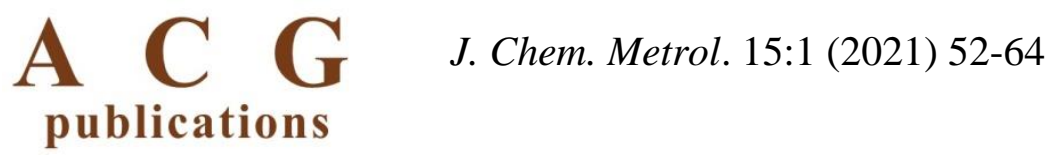

\title{
Investigation of aflatoxin and metal concentrations in animal feeds and feed ingredients from Turkey
}

\section{Yasemin Bakircioglu Kurtulus ${ }^{1, *}$, Dilek Bakircioglu ${ }^{1}$, Muhammet Kuscu $\oplus^{2}$, Nukte Topraksever ${ }^{1}{ }^{1}$ and Orhan Destanoglu $\oplus^{3}$}

\author{
${ }^{I}$ Trakya University, Faculty of Science, Chemistry Department, Edirne, Türkiye \\ ${ }^{2}$ Ministry of Agriculture and Forestry, Kocaeli Food Control Laboratory, Kocaeli, Türkiye \\ ${ }^{3}$ Istanbul University-Cerrahpasa, Institute of Forensic Science and Legal Medicine, Department of \\ Science, Istanbul, Türkiye
}

(Received January 09, 2021; Revised February 23, 2021; Accepted February 24, 2021)

\begin{abstract}
The contents of aflatoxin $\mathrm{B}_{1}\left(\mathrm{AFB}_{1}\right)$, aflatoxin $\mathrm{B}_{2}\left(\mathrm{AFB}_{2}\right)$, aflatoxin $\mathrm{G}_{1}\left(\mathrm{AFG}_{1}\right)$ aflatoxin $\mathrm{G}_{2}\left(\mathrm{AFG}_{2}\right)$, aluminium $(\mathrm{Al})$, arsenic $(\mathrm{As})$, barium $(\mathrm{Ba})$, calcium $(\mathrm{Ca})$, cadmium $(\mathrm{Cd})$, cobalt $(\mathrm{Co})$, chromium $(\mathrm{Cr})$, copper $(\mathrm{Cu})$, iron $(\mathrm{Fe})$, mercury $(\mathrm{Hg})$, potassium $(\mathrm{K})$, magnesium $(\mathrm{Mg})$, manganese $(\mathrm{Mn})$, sodium $(\mathrm{Na})$, nickel $(\mathrm{Ni})$, phosphorus $(\mathrm{P})$, lead $(\mathrm{Pb})$, selenium $(\mathrm{Se})$, tin $(\mathrm{Sn})$ and zinc $(\mathrm{Zn})$ in animal feed samples in Turkey were screened. Eighty animal feeds and feed ingredients were collected from different cities in Turkey. Aflatoxins were determined using the HPLC instrument after pre-separation using immuno affinity column, and also the instrument of ICP-MS was used for metal determinations. All types of animal feed samples have led concentrations lower than the maximum EU and Turkey regulation limit, while $1.25 \%$ and 11.8 of mixed and feed additive samples had $\mathrm{AFB}_{1}$ and $\mathrm{Hg}$ concentrations higher than the maximum limits, respectively. A single correlation analysis was used to determine the relationship between $\mathrm{AFB}_{1}$ and total $\mathrm{AFs}$ and metal contents in mixed animal feed samples $(\mathrm{p}<0.05)$. A strong positive correlation was found between $\mathrm{As}$ and $\mathrm{AFB}_{1}$ and total $\mathrm{AFs}$ contents; whereas $\mathrm{Cr}$ was correlated negatively to $\mathrm{AFB}_{1}$ and total $\mathrm{AFs}$, using single correlation analyses.
\end{abstract}

Keywords: Animal feed; aflatoxins; metals; HPLC, ICP-MS; correlation analyses. @ 2021 ACG Publications. All rights reserved.

\section{Introduction}

Mycotoxins possessing low molecular weights $(\mathrm{MW} \leq 700)$ are chemical compounds produced by certain molds (Aspergillus, Fusarium, Penicillium, Aternaria, Claviceps, etc.). Today, more than 500 species of mycotoxin are known while aflatoxin, ochratoxin, deoxynivalenol, zearalenone, fumonisin, and patulin are among the well-known mycotoxins. Mycotoxins can be produced in plant products by means of fungal contamination during either pre-harvest (field level) or post-harvest conditions (storage, transport, and processing) [1,2]. Aflatoxins are secondary metabolites of Aspergillus flavus, Aspergillus parasiticus, Aspergillus nomius, Aspergillus bombycis species [3,4]. There are four types of aflatoxins: aflatoxin $\mathrm{G}_{1}\left(\mathrm{AFG}_{1}\right)$, aflatoxin $\mathrm{G}_{2}\left(\mathrm{AFG}_{2}\right)$, aflatoxin $\mathrm{B}_{1}\left(\mathrm{AFB}_{1}\right)$, and aflatoxin $\mathrm{B}_{2}\left(\mathrm{AFB}_{2}\right)$. Aspergillus flavus is responsible for the production of aflatoxin $B_{1}$ and $B_{2}$ while aflatoxin $G_{1}, G_{2}, B_{1}$, and $B_{2}$ can be produced by Aspergillu sparasiticus [5]. Aflatoxins are difuran-based coumarin compounds. They are classified in two sub-groups as difurocoumarocyclopentenone $\left(\mathrm{AFB}_{1}\right.$ and $\left.\mathrm{AFB}_{2}\right)$ and difurocoumarolactone $\left(\mathrm{AFG}_{1}\right.$ and $\left.\mathrm{AFG}_{2}\right)$. They have fluorescence property and absorb strongly UV light

\footnotetext{
*Corresponding author E-Mail: ybakircioglu@trakya.edu.tr
} 
at $362 \mathrm{~nm}$; and blue (from $\mathrm{AFB}_{1}$ and $\left.\mathrm{AFB}_{2}\right)$, green $\left(\mathrm{AFG}_{1}\right)$, and blue-green $\left(\mathrm{AFG}_{2}\right)$ colors are exhibited by emitting light at $425-450 \mathrm{~nm}[6]$.

The suitable factors for the production of aflatoxins are of biological, chemical, and environmental origins. Biological and chemical factors are the source elements of plant products or foodstuffs involving water activity, $\mathrm{pH}$, chemical composition, and level of maturity at harvest. Environmental factors are the temperature conditions, relative humidity conditions, oxygen level, amount of light, climate of the place where the product is grown, the geographic region, and the processing of the product (storage, drying techniques) [1].

Aflatoxins are commonly present in herbal products. Nuts (hazelnuts, pistachios, peanuts), grains (wheat, corn, barley, rye, rice, oats), cereal products (bran, flour), oil seeds (sesame, sunflower, rapeseed, cottonseed), coffee beans, cocoa, spices (black pepper, red pepper), and dried fruits (raisins, dried figs) are the most encountered plant-derived products [7]. Animal feeds are contaminated with aflatoxins due to the raw materials used in feeds like millet, corn, sorghum, and bagasse of peanut, sunflower, soy, and cotton seed. Additionally, aflatoxins can be found in dairy milk and milk products as aflatoxin $\mathrm{M}_{1}$ metabolite [8[. The effects of aflatoxins show varieties in animals (monkeys, trout, rats etc.) depending on exposure dose, duration, type, genus, dietary or nutritional status, and general health status. Additionally, they can cause serious health complications such as cancer, liver damage, decrease in milk production, immune suppression, and anemia [6]. People can be directly or indirectly exposed to aflatoxins [5]. According to a report published in 1993 by the International Agency for Research on Cancer, aflatoxin $\mathrm{B}_{1}$ is classified as a carcinogenic substance (group 1) for humans [9].

Determination of aflatoxins in food and feed samples is generally based on the extraction procedure of the toxin from the matrix and quantitation with different analytical techniques. Immunosensors-immunochemical methods [10-12], Thin-layer chromatography (TLC) [8], Gas chromatography [13], High-performance liquid chromatography (HPLC) [8,14] and Fourier transform infrared spectrometry (FTIR) [15] have been performed for qualitative and quantitative analyses of aflatoxins. In the extraction of the aflatoxins from matrices, some organic solvents such as chloroform, dichloromethane, methanol, acetonitrile, and acetone [16,17] were used.

Aflatoxins and elements are potential environmental contaminants that cause serious problems for human health, and it is important to monitor these pollutants in animal feed [18]. Metal-based fertilizer application, pesticides, post-harvest contamination, industrial-based activities, and anthropogenic activities can cause soil contamination [18,19]. Plant materials grown in contaminated soils can be eaten by grazing animals and then transferred to human food through milk, meat, or other animal products [20]. Animal foods containing healthy food proteins are important for the human diet. For this reason, eaten by animal are the main determinants of human health and quality [21,22]. However, all elements of a high level in different animal feed species can cause some negative health problems in animals. Some elements such as $\mathrm{Cd}, \mathrm{Pb}, \mathrm{Zn}$, and $\mathrm{Cu}$ have harmful effects on poultry feeds. In poultry, these elements accumulate in the kidneys and liver and cause toxic effects [23]. For these reasons, the determination of the elements in animal feeds is necessary for human health [24]. Limited information is available on the presence and determination of elements in feed materials, premixes, and finished feed. In recent years, many atomic spectroscopic techniques (flame atomic absorption spectrometry, graphite-furnace atomic absorption spectrometry, inductively coupled plasma optical emission or mass spectrometry) have been widely used in quantitative determinations of elements in different matrixes [25-28]. Inductively coupled plasma mass spectrometry (ICP-MS) is preferred to other spectroscopic methods because of its advantages such as precision, high selectivity, wide linear range, and multiple element determinations.

In this work, the determination of elements and $\mathrm{AFB}_{1}, \mathrm{AFB}_{2}, \mathrm{AFG}_{1}$, and $\mathrm{AFG}_{2}$ have been undertaken in different types of animal feed samples. The interrelationships between the elements and the content of aflatoxins in animal feed samples have not been given in the literature. In addition, the relationship between the concentrations of elements and aflatoxins in animal feeds have been undertaken statistically using correlation analysis for the first time. 


\section{Experimental}

\subsection{Reagents and Solutions}

$\mathrm{KBr}(99.9 \%), \mathrm{HNO}_{3}(65 \%)$ (Suprapur®), $\mathrm{H}_{2} \mathrm{O}_{2} 30 \%, \mathrm{NaCl}$ (99.9 \%), $\mathrm{H}_{2} \mathrm{SO}_{4}(99.9 \%), \mathrm{KOH}(99.9$ $\%$ ), and HPLC grade acetonitrile, acetone, and methanol were purchased from Merck (Darmstadt, Germany). The mix standard stock solution containing $\mathrm{AFB}_{1}(1000 \mathrm{ng} / \mathrm{mL}), \mathrm{AFB}_{2}(300 \mathrm{ng} / \mathrm{mL}), \mathrm{AFG}_{1}$ $(1000 \mathrm{ng} / \mathrm{mL})$, and $\mathrm{AFG}_{2}(300 \mathrm{ng} / \mathrm{mL})$ were obtained from Supelco Chemical Company (USA). The mix standard stock solution was diluted with methanol to $10 \mathrm{~mL}$ in order to prepare second level standard stock solution. Working standard solutions were prepared from second level standard solution with methanol-water mixture. The certificated reference material (ERM-BE 376 Compound Feeding stuff) was taken from European Reference Material. Argon and helium purity was higher than $99.999 \%$.

\subsection{Insturuments}

Agilent 7700 ICP-MS instrument (Santa Monica, CA, USA) was used for elemental analysis and the auto-sampler (ASX-500) was also used. Operating conditions for ICP-MS measurements were: forward power $1.6 \mathrm{~kW}$, sampling depth $10 \mathrm{~nm}$, sample uptake flow rate $0.3 \mathrm{~mL} / \mathrm{min}$, carrier gas flow rate $0.35 \mathrm{~L} / \mathrm{min}$, dilution gas flow rate $0.6 \mathrm{~L} / \mathrm{min}$, cell gas flow rate $\mathrm{He} 5 \mathrm{~mL} / \mathrm{min}$ and spray chamber temperature $2{ }^{\circ} \mathrm{C}$. A microwave device (MARSXpress, CEM Corporation, Matthews, North Carolina) was used for element digestion from the feed samples. In order to homogenize of samples blender (Waring 1200) was used.

The chromatographic analyses of the aflatoxins were carried out by utilizing an Agilent 1100 Series HPLC system (Palo Alto, CA, USA). The chromatographic separations of aflatoxins were achieved on the $\mathrm{C} 18$ analytical column $(250 \mathrm{~mm} \times 4.6 \mathrm{~mm}, 5 \mu \mathrm{m})$ obtained from ACE (Aberdeen, Scotland). The aflatoxins were detected by performing an Agilent Fluorescence Detector (FLD). Immunoaffinity columns (AflaTest) were purchased from VICAM (USA). A stainless steel blender possessing $1 \mathrm{~L}$ volume was taken from Waring Products, Inc. (USA).

\subsection{Sample Collection and Preparation for Aflatoxin and Metal Determinations}

Eighty different types of animal feed (three sample of each) were supplied from various feed factories or companies in Kocaeli, Sakarya, and Yalova areas in Turkey. From the 80 feed samples, 36 of them were compound feed, 18 of them were cattle feed (feeding, milk and young cattle feed), three of them were lamb feed, six of them were poultry feed (chicken growth feed and chick feed), and 17 of them were feed materials ( 7 types of soybean meal, 8 types of sunflower meal, one type of corn, and one type of feedstuff).

All samples were ground to fine powder with a stainless-steel blender. Each $500 \mathrm{~g}$ of sample was sieved, and then the powder containing particle of one $\mathrm{mm}$ in size was collected. After the samples were placed into polyethylene storage containers, they were labeled, numbered, and kept at $+4^{\circ} \mathrm{C}$ until analysis. The concentrations of total aflatoxin, $\mathrm{AFB}_{1}, \mathrm{AFB}_{2}, \mathrm{AFG}_{1}, \mathrm{AFG}_{2}$ and studied elements were screened using the procedures given below.

\subsection{Metal Determination}

The total concentrations of studied elements were screened by using after microwave digestion. One gram of compound feed, lamb feed, cattle feed, poultry feed, and feed additive samples were transferred into microwave digestion vessels containing six $\mathrm{mL}$ of $65 \% \mathrm{HNO}_{3}$, and then two $\mathrm{mL}$ of $30 \%$ $\mathrm{H}_{2} \mathrm{O}_{2}$ was added to each vessel. Digestion conditions for the microwave system were applied as follows: $250 \mathrm{~W}$ for two min, $0 \mathrm{~W}$ for two min, $250 \mathrm{~W}$ for six min, $400 \mathrm{~W}$ for five min, and $550 \mathrm{~W}$ eight min, vent for $15 \mathrm{~min}$. After cooling to room temperature, ultra-pure water was added to a volume of $50 \mathrm{~mL}$, and then the element concentrations were determined by ICP-MS [29]. All experiments were performed in triplicate. The calibration graphs were prepared using multi-element standard solutions contained $0.5,1.0$, 5.0, 10.0, 20.0, 30.0, 40.0, and 50.0 $\mu \mathrm{g} / \mathrm{L}$ for As, $\mathrm{Ba}, \mathrm{Cd}, \mathrm{Co}, \mathrm{Cr}, \mathrm{Hg}, \mathrm{Ni}, \mathrm{Pb}$, and $\mathrm{Sn}$ 25.0, 50.0, 100.0, 250.0 , and $500.0 \mu \mathrm{g} / \mathrm{L}$ for $\mathrm{Al}, \mathrm{Ca}, \mathrm{Cu}, \mathrm{Fe}, \mathrm{Mg}, \mathrm{Mn}, \mathrm{Na}, \mathrm{Se}$, and $\mathrm{Zn}$. The limits of detection calculating to the $3 s$ criterion were $16.4,7.6,4.8,200,10.3,4.6,8.5,12.3,3.8,36.7,78.0,12.3,578,0.97,7.8,9.6,46.4$, 
and $0.40 \mu \mathrm{g} / \mathrm{L}$ for $\mathrm{Al}, \mathrm{As}, \mathrm{Ba}, \mathrm{Ca}, \mathrm{Cd}, \mathrm{Co}, \mathrm{Cr}, \mathrm{Cu}, \mathrm{Fe}, \mathrm{Hg}, \mathrm{Mg}, \mathrm{Mn}, \mathrm{Na}, \mathrm{Ni}, \mathrm{Pb}, \mathrm{Se}, \mathrm{Sn}$, and $\mathrm{Zn}$, respectively.

\subsection{Afltoxin Determination}

The AOAC official standard method was used for the analysis of the animal feeds, feed ingredients, and certified materials [30]. Ten gram of $\mathrm{NaCl}$ and $250 \mathrm{~mL}$ of $\mathrm{MeOH}: \mathrm{H}_{2} \mathrm{O}$ (70:30) solution was added to $50 \mathrm{~g}$ of the sample, respectively for HPLC analysis. The sample was mixed by using the blender at medium speed for $2 \mathrm{~min}$. The extracts were filtered by Whatman (No-4) filter paper. $20 \mathrm{~mL}$ of filtrates were diluted with $40 \mathrm{~mL}$ of double distilled water. $15 \mathrm{~mL}$ of mixture was passed through immune affinity column at a flow rate of about 1-2 drop/s using a syringe. Then, the immune affinity column was washed with $10 \mathrm{~mL}$ of water. Aflatoxins were eluted by using one $\mathrm{mL}$ of methanol. The eluate was diluted with water and then transferred into amber HPLC vials for injection.

Aflatoxin $B_{2}$ and $G_{2}$ can produce analytically useful fluorescence at adequate intensity in aqueous mobile phases. Yet, fluorescent intensities of aflatoxin $B_{1}$ and $\mathrm{G}_{1}$ were very weak. Therefore, a postcolumn derivatization (PCD) treatment was conducted using an electrochemical cell (Coring-Cell, Coring System Diagnostics GmbH, Germany, $100 \mu \mathrm{A}$ ) in order to increase fluorescence intensities of aflatoxin $B_{1}$ and aflatoxin $G_{1}$. The derivatizing agent was bromine formed in the cell using bromide present in the mobile phase. Because free bromine absorbs some light in the cell [30], baseline drops down. Thus, 120 $\mathrm{mg} \mathrm{KBr}$ and $350 \mu \mathrm{L}$ of $4 \mathrm{M} \mathrm{HNO}_{3}$ were added into each one $\mathrm{L}$ mobile phase. This system is capable of derivatizing in a short period of four seconds, so the analysis completed in a short time. On this count, four main types of aflatoxins were simultaneously observed in the same chromatogram. The experiments were performed in triplicate.

The mobile phase (isocratic) composition was $\mathrm{H}_{2} \mathrm{O}: \mathrm{MeOH}: \mathrm{ACN}(56: 26: 18$, v/v/v) with $120 \mathrm{mg}$ $\mathrm{KBr}$ and $350 \mu \mathrm{L}$ of $4 \mathrm{M} \mathrm{HNO}_{3}$. The mobile phase was delivered at a flow rate of $1.0 \mathrm{~mL} / \mathrm{min}$ with an isocratic mode. Fluorescence detector was used. The excitation wavelength was $360 \mathrm{~nm}$ while emission wavelength was $430 \mathrm{~nm}$, the injection volume was $100 \mu \mathrm{L}$; and the column temperature was $25^{\circ} \mathrm{C}$.

\subsection{Validation of the HPLC Method}

Prior to measurement of aflatoxins in animal feeds and feed ingredients, this HPLC method was validated for its linearity, selectivity, accuracy, precision, limit of detection (LOD), limit of quantification (LOQ), and recovery. Linearity was evaluated by injecting aflatoxins standard solutions in the following ranges: 0.40-7.20 ng/mL for $\mathrm{AFB}_{1}$ and $\mathrm{AFG}_{1} ; 0.12-2.16 \mathrm{ng} / \mathrm{mL}$ for $\mathrm{AFB}_{2}$, and $\mathrm{AFG}_{2}$ with five calibration levels, each injected in triplicate. To test the recoveries of proposed HPLC method used for aflatoxins, non-infected animal feeds and feed ingredients samples were spiked with $0.50 \mu \mathrm{g} / \mathrm{kg} \mathrm{AFB}, \mathrm{AFG}_{1}$, and $0.15 \mu \mathrm{g} / \mathrm{kg}$ of $\mathrm{AFB}_{2}, \mathrm{AFG}_{2}$. Ten experiments were repeated on spiked samples for each matrix. LOD and LOQ were determined by the spiked samples based on signal-to-noise (S/N) ratio of 3:1 for LOD and 10:1 for LOQ. The accuracy of the method was tested with certified reference material ERM-BE 376 Compound Feeding stuff. Precision was obtained by performing eleven analysis of the reference material and given by relative standard deviation (RSD \%).

\subsection{Statistical Analysis}

The correlation between aflatoxins and metals were made using Minitab 18.1, and $t$ values were calculated using Microsoft Excel 2013 programme. A probability value of 0.05 was used to determinate the statistical significance.

\section{Results and discussion}

\subsection{Optimization of HPLC Extraction Process}

Acetone, acetonitrile, methanol, and chloroform have been used at varying rates for extracting the aflatoxins from different types of samples since aflatoxins are soluble in polar solvents $[16,17]$. In this study, acetone, methanol, and acetonitrile mixtures was examined for optimizing the proposed extraction procedure. Due to its environmentally polluting nature, chloroform was not used. Extraction yield studies 
of $\mathrm{AFB}_{1}, \mathrm{AFB}_{2}, \mathrm{AFG}_{1}$, and $\mathrm{AFG}_{2}$ in different concentration of spiked $(1.3,2.6,5.2,10.4$ and $15.6 \mathrm{mg} / \mathrm{mL})$ animal feed and feed ingredients samples were performed by using different proportions of $\mathrm{MeOH}: \mathrm{H}_{2} \mathrm{O}$ $(60: 40 \%, 70: 30 \%, 80: 20 \%), \mathrm{ACN}: \mathrm{H}_{2} \mathrm{O}(55: 45 \%, 70: 30 \%, 85: 15 \%)$, and Acetone: $\mathrm{H}_{2} \mathrm{O}(55: 45 \%, 70: 30$ $\%, 85: 15 \%)$ solvent mixture. When acetone: $\mathrm{H}_{2} \mathrm{O}$ mixtures were used, the recovery values were found in the ranges of 0-167 \%, 6-175\%, 0-37\%, and 11-154\% for $\mathrm{AFG}_{2}, \mathrm{AFG}_{1}, \mathrm{AFB}_{2}$, and $\mathrm{AFB}_{1}$, respectively. In addition, the extraction yields obtained by using $\mathrm{ACN}: \mathrm{H}_{2} \mathrm{O}$ mixtures were found to be $0-145 \%, 0-20 \%$, $0-175 \%$, and $0-146 \%$ for $\mathrm{AFG}_{2}, \mathrm{AFG}_{1}, \mathrm{AFB}_{2}$, and $\mathrm{AFB}_{1}$, respectively. In the $\mathrm{MeOH}: \mathrm{H}_{2} \mathrm{O}$ solvent mixtures, the most stable and highest recovery rates of the aflatoxins studied were obtained. When using different $\mathrm{MeOH}: \mathrm{H}_{2} \mathrm{O}$ solvent mixtures for different concentrations of $\mathrm{AFG}_{2}$, the highest recovery was found at 60:40, and the lowest recovery was 80:20. However, since the standard deviation values of the 60:40 MeOH: $\mathrm{H}_{2} \mathrm{O}$ mixture were greater than 70:30, the mixture of $70: 30 \mathrm{MeOH}: \mathrm{H}_{2} \mathrm{O}$ was decided with $\mathrm{AFG}_{2}$ analysis for animal feed and feed ingredients. Similar results were obtained in $\mathrm{AFB}_{1}$ and $\mathrm{AFB}_{2}$ for studied MeOH: $\mathrm{H}_{2} \mathrm{O}$ solvent mixtures. For $\mathrm{AFG}_{1}$, it was observed that the highest recovery values were in 70:30 and 80:20 MeOH: $\mathrm{H}_{2} \mathrm{O}$ solvent mixtures, and the standard deviation values were in low these two solvent mixtures. Therefore, for all aflatoxin species studied, 70:30 MeOH: $\mathrm{H}_{2} \mathrm{O}$ was decided as an extract of solution in the following studies.

\subsection{Aflatoxin Methods Validation}

When samples with non-infected animal feeds and feed ingredients were analyzed, no interferences were observed with the aflatoxin peaks at the retention of each compounds. However, toxin peaks were observed without the appearance of shoulders and interferences when added to actual samples containing aflatoxin. Chromatograms obtained from a standard solution, standard reference material, and mixed feed sample (No 12) are shown in Figure 1, 2, and 3.

Selectivity, linearity, detection limit (LOD), quantitative limit (LOQ), recovery, accuracy, and precision were determined to test the validity of the procedures used in detecting AFs. The linearity, LOD, LOQ, and recovery percentages for each aflatoxin in animal feeds, and ingredients samples are given in Table 1 .

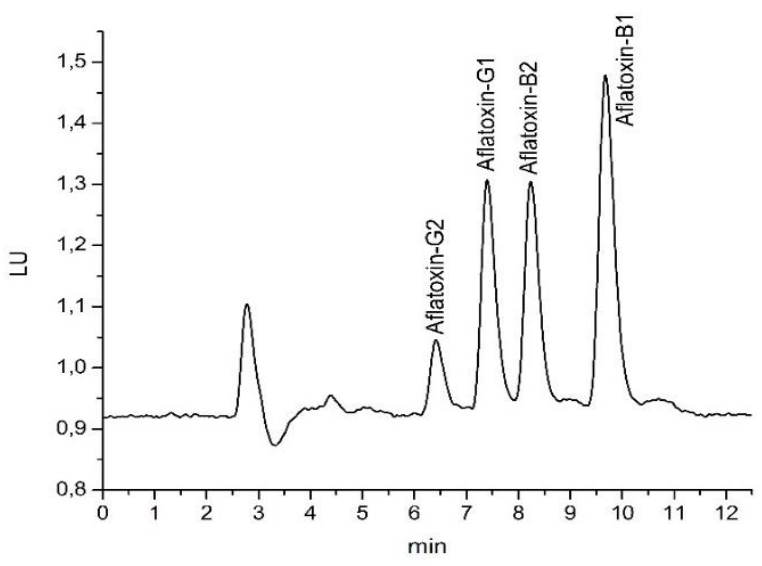

Figure 1. Chromatogram of the mixed standard solution of $\mathrm{AFB}_{1}$ and $\mathrm{AFG}_{1}=6.0 \mathrm{ng} / \mathrm{g}$, $\mathrm{AFB}_{2}$ and $\mathrm{AFG}_{2}=1.80 \mathrm{ng} / \mathrm{g}$ and totally $=15.60 \mathrm{ng} / \mathrm{g}$ $(\mathrm{Ex}=360 \mathrm{~nm} ; \mathrm{Em}=430 \mathrm{~nm})$

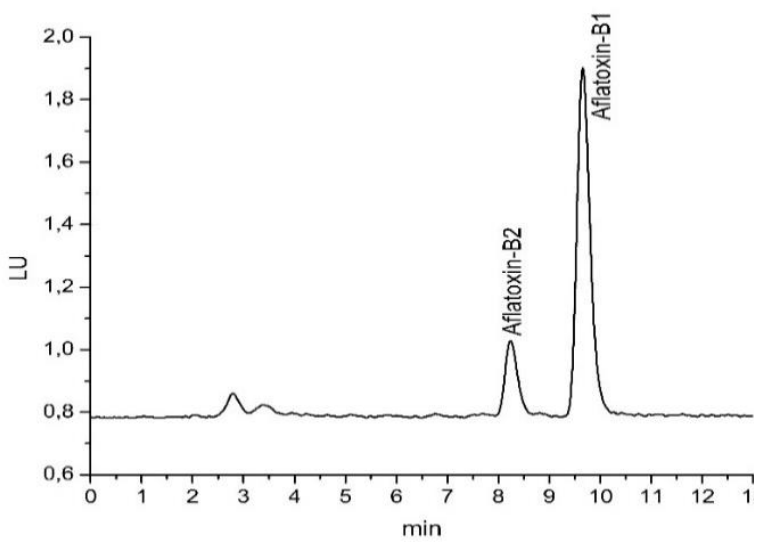

Figure 2. Chromatogram of the ERM-BE 376 Compound Feedingstuff solution $(\mathrm{Ex}=360 \mathrm{~nm} ; \mathrm{Em}=430 \mathrm{~nm})$ 


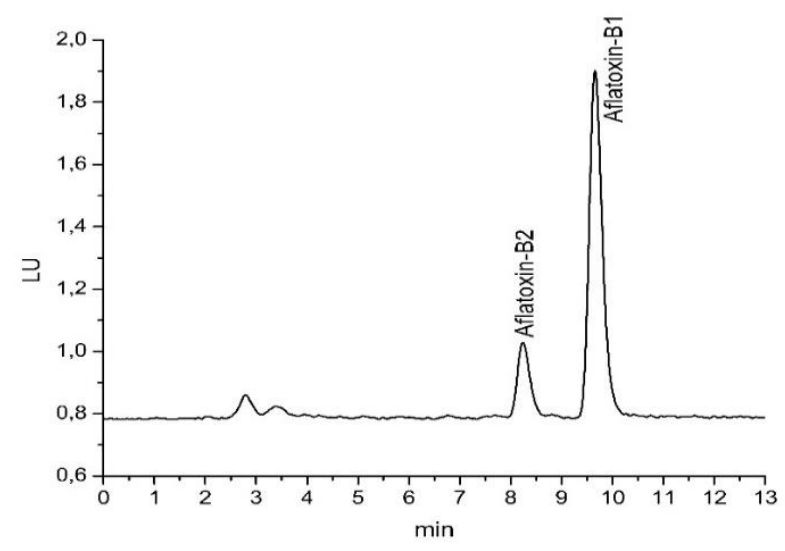

Figure 3. Chromatogram of the mixed feed sample (No 12) containing $\mathrm{AFB}_{1}=122.51 \mathrm{ng} / \mathrm{g}$ and $\mathrm{AFB}_{2}=$ $10.76 \mathrm{ng} / \mathrm{g}(\mathrm{Ex}=360 \mathrm{~nm} ; \mathrm{Em}=430 \mathrm{~nm})$

In general, good linearity was obtained for all aflatoxins studied. The correlation coefficients $\mathrm{R}^{2}$ were in the range from 0.9935 to 0.9996 . The mean recoveries of aflatoxins from non-infected animal feeds samples were spiked with $\mathrm{AFB}_{1}$ and $\mathrm{AFG}_{1}$ at concentrations of $0.50 \mu \mathrm{g} / \mathrm{kg}$ and were between $96 \%$ and $104 \%$. The recoveries values obtained for $\mathrm{AFB}_{2}$ in spiked samples at a concentration of $0.15 \mathrm{of} \mu \mathrm{g} / \mathrm{kg}$ were found to be $80 \%$ while it was $40 \%$ for $\mathrm{AFG}_{2}$. The LODs ( $\mathrm{S} / \mathrm{N}=3$ ) were $27,11,16$, and $10 \mathrm{ng} / \mathrm{kg}$ for $\mathrm{AFB}_{1}, \mathrm{AFB}_{2}, \mathrm{AFG}_{1}$, and $\mathrm{AFG}_{2}$, repectively, and the LOQs ( $\left.\mathrm{S} / \mathrm{N}=10\right) 90,4,54$, and $34 \mathrm{ng} / \mathrm{kg}$ for $\mathrm{AFB}_{1}$, $\mathrm{AFB}_{2}, \mathrm{AFG}_{1}$, and $\mathrm{AFG}_{2}$, respectively. Accuracy was examined by the determination of the certified reference material ERM-BE 376 Compound Feedingstuff of the AFs. The results obtained showed that proposed method is selective and accurate (Table 2). They are in good agreement considering one sample $t$ test at a $95 \%$ confidence limit. The precision of the methods was evaluated calculating the relative standard deviation (RSD) of eleven analyses performed on each reference material ERM-BE 376. The average RSD for repeatability of reference material ERM-BE 376 measurements were in the range of 6.21-10.6\%. A typical chromatogram obtained for AFs in certified reference material is shown in Figure 3.

\subsection{Aflatoxin Determination}

The results of the analyses of $\mathrm{AFB}_{1}, \mathrm{AFB}_{2}, \mathrm{AFG}_{1}, \mathrm{AFG}_{2}$, and total $\mathrm{AFs}$ in the 80 animal feed samples are given in Table 3 . In the samples of various animal feeds analyzed, $\mathrm{AFB}_{1}$ in 50 samples, $\mathrm{AFB}_{2}$ in 32 samples, $\mathrm{AFG}_{1}$ in 9 samples, and $\mathrm{AFG}_{2}$ in eight samples were determined. In only three of the samples, four types of aflatoxins were present together. There were three types of aflatoxins present at the same time in seven samples. The number of samples with two aflatoxins determined at the same time was found to be 24, and 19 samples were found to contain only one species of aflatoxin. When the results of $\mathrm{AFB}_{1}$ were analyzed; $\mathrm{AFB}_{1}$ was not detected in $37.5 \%$ of the samples. However, in $35 \%$ of the samples analyzed, aflatoxin amount was in the range of $0.1-1.0 \mu \mathrm{g} / \mathrm{kg}$. The sample containing $\mathrm{AFB}_{1}$ in the range of 1.0 to $10.0 \mu \mathrm{g} / \mathrm{kg}$ was $20 \%$ of all samples analyzed and $6.25 \%$ in the range of $10.0-20.0 \mu \mathrm{g} / \mathrm{kg}$. In addition, the number of samples containing $\mathrm{AFB}_{1}$ determined at a concentration greater than the 20.0 $\mu \mathrm{g} / \mathrm{kg}$ was determined as $1.25 \%$ of all samples. Aflatoxin $\mathrm{B}_{1}$ was detected in most samples analyzed, and the levels ranged from 0.12 to $122.51 \mu \mathrm{g} / \mathrm{kg}$.

According to the regulation in the European Union countries, $\mathrm{AFB}_{1}$ levels for feed materials and feed compounds (cattle, sheep and poultry) are expressed as $20 \mu \mathrm{g} / \mathrm{kg}$, while the $\mathrm{AFB}_{1}$ level feed compounds for dairy animals (cattle, sheep, lamb, and young poultry) and complementary and complete feeds is $5 \mu \mathrm{g} / \mathrm{kg}$ and $10 \mu \mathrm{g} / \mathrm{kg}$, respectively ${ }^{31}$. For feed materials and compound feed for dairy animals (cattle, sheep, lamb) given by Republic of Turkey Ministry of Agriculture and Rural Affairs AFB 1 limit values are given as $20 \mu \mathrm{g} / \mathrm{kg}$ and $5 \mu \mathrm{g} / \mathrm{kg}$, respectively [32]. When the animal feed samples analyzed in this study, only one sample was found exceeding the limit of $20 \mu \mathrm{g} / \mathrm{kg} \mathrm{AFB}_{1}$ limit value for compound feeds according to Turkish regulation (Table 3 ). 
Table 1. Method performance parameters determined in feed samples

\begin{tabular}{|c|c|c|c|c|c|c|c|c|c|}
\hline Analyte & $\begin{array}{l}\text { Linear } \\
\text { Range } \\
(\mathbf{n g} / \mathbf{m L})\end{array}$ & $\begin{array}{l}\text { Regression } \\
\text { Equation }^{a}\end{array}$ & $\mathbf{R}^{2}$ & $\begin{array}{l}\text { Retention } \\
\text { time } \\
\text { (min) }\end{array}$ & $\begin{array}{l}\text { AFs spike } \\
\text { concentration } \\
(\mu \mathrm{g} / \mathrm{kg})^{\mathrm{b}}\end{array}$ & $\begin{array}{l}\text { Recovery } \\
\%\end{array}$ & $\begin{array}{l}\text { RSD } \\
\%\end{array}$ & $\begin{array}{l}\text { LOD } \\
\text { (ng/kg) }\end{array}$ & $\begin{array}{l}\text { LOQ } \\
\text { (ng/kg) }\end{array}$ \\
\hline $\mathrm{AFB}_{1}$ & $0.4-7.2$ & $y=5.77 x-0.19$ & 0.9996 & 9.71 & 0.50 & 96 & 10.8 & 27 & 90 \\
\hline $\mathrm{AFB}_{2}$ & $0.12-2.16$ & $y=11.46 x-0.25$ & 0.9972 & 8.26 & 0.15 & 80 & 3.3 & 11 & 4 \\
\hline $\mathrm{AFG}_{1}$ & $0.4-7.2$ & $y=4.00 x-1.51$ & 0.9948 & 7.42 & 0.50 & 104 & 4.0 & 16 & 54 \\
\hline $\mathrm{AFG}_{2}$ & $0.12-2.16$ & $y=4.25 x-0.43$ & 0.9935 & 6.43 & 0.15 & 40 & 14.4 & 10 & 34 \\
\hline
\end{tabular}

${ }^{\mathrm{a}} \mathrm{n}=3$

${ }^{\mathrm{b}} \mathrm{n}=10$

Table 2. Determination of aflatoxins in the Certified Reference Material (ERM-BE376) ( $\mu \mathrm{g} / \mathrm{kg}, \mathrm{n}=11$ )

\begin{tabular}{llllll}
\hline Analyte & Certified value & Found & RSD \% & Recovery \% \\
\hline $\mathrm{AFB}_{1}$ & $12.9 \pm 1.76$ & $10.97 \pm 1.16$ & 10.6 & 87.4 \\
$\mathrm{AFB}_{2}$ & $0.68 \pm 0.1$ & $0.45 \pm 0.07$ & 15.6 & 64.8 \\
$\mathrm{AFG}_{1}$ & $5.2 \pm 0.8$ & $4.51 \pm 0.28$ & 6.21 & -3.56 & 85.3 \\
\hline
\end{tabular}

$\mathrm{t}_{\text {ciritical }}=2.23$

Table 3. Presence of aflatoxins in different animal feed samples by HPLC analysis

\begin{tabular}{|c|c|c|c|c|c|c|c|c|c|c|}
\hline \multirow{3}{*}{$\begin{array}{l}\text { Sample } \\
\text { category }\end{array}$} & \multicolumn{10}{|c|}{ Aflatoxins $(\mu \mathrm{g} / \mathrm{kg})$} \\
\hline & \multicolumn{2}{|c|}{$\overline{\Sigma A F s} \mathbf{s}^{\mathbf{a}}$} & \multicolumn{2}{|l|}{$\mathbf{A F B}_{1}$} & \multicolumn{2}{|l|}{$\mathbf{A F B}_{2}$} & \multicolumn{2}{|c|}{$\mathbf{A F G}_{1}$} & \multicolumn{2}{|c|}{$\mathbf{A F G}_{2}$} \\
\hline & No. ${ }^{b}$ & Range & No. ${ }^{b}$ & Range & No. ${ }^{b}$ & Range & No. ${ }^{b}$ & Range & No. ${ }^{b}$ & Range \\
\hline Mixed Feed & $36 / 24$ & $0.24-19.70 ; 133.28$ & $36 / 24$ & $0.14-7.3 ; 122.51$ & $36 / 14$ & $0.04-0.63 ; 10.76$ & $36 / 1$ & 0.41 & $36 / 1$ & 1.20 \\
\hline Lamb Feed & $3 / 3$ & $0.63-1.23 ; 19.70$ & $3 / 3$ & $0.38-18.12$ & $3 / 2$ & $0.079-1.57$ & $3 / 0$ & $\mathrm{ND}^{\mathrm{c}}$ & $3 / 1$ & 0.85 \\
\hline Cattle Feed & $18 / 14$ & $0.12-8.79 ; 12.43$ & $18 / 14$ & $0.12-11.62$ & $18 / 9$ & $0.03-0.84$ & $18 / 3$ & $0.11-0.84$ & $18 / 1$ & 0.10 \\
\hline Poultry Feed & $6 / 4$ & $0.20-4.54 ; 12.4$ & $6 / 4$ & $0.20-3.2 ; 11.72$ & $6 / 3$ & $0.04-0.67$ & $6 / 2$ & $0.2-0.88$ & $6 / 0$ & ND \\
\hline Feed Additives & $17 / 7$ & $0.21-1.15 ; 10.78$ & $17 / 5$ & $0.21-0.75 ; 10.16$ & $17 / 4$ & $0.037-0.62$ & $17 / 3$ & $0.11-0.26$ & $17 / 5$ & $0.065-0.30$ \\
\hline
\end{tabular}

${ }^{\mathrm{a}} \Sigma \mathrm{AFs}=\Sigma\left(\mathrm{AFB}_{1}+\mathrm{AFB}_{2}+\mathrm{AFG}_{1}+\mathrm{AFG}_{2}\right)$.

${ }^{b}$ Incidence no was represented by total/positive sample of particular category.

${ }^{c}$ Not detected 
Additionally, the limit of $5 \mu \mathrm{g} / \mathrm{kg}$ of $\mathrm{AFB}_{1}$ determined for dairy animals was exceeded in only two samples $(6.89$ and $11.62 \mu \mathrm{g} / \mathrm{kg})$. The limit value of $\mathrm{AFB}_{1}$ in complementary and complete feeds is 10 $\mu \mathrm{g} / \mathrm{kg}$ in the regulation of the European Union Countries [31]. When the results obtained according to this regulation were evaluated, five samples exceeding the limit value were determined. The European Community has established that maximum levels of $\mathrm{AFM}_{1}$ in raw milk, heat-treated milk and milk for the manufacture of milk-based products should not exceed $50 \mathrm{ng} / \mathrm{kg}[33,34]$. In addition, the daily amount of $\mathrm{AFB}_{1}$ passing through the milk as $\mathrm{AFM}_{1}$ is 0.17 to $3.3 \%$ [35]. As a result, $\mathrm{AFB}_{1}$ values in the feed samples analyzed for this study exceeded the $\mathrm{AFM}_{1}$ limit values in only one sample $(122.51 \mu \mathrm{g} / \mathrm{kg})$.

The main reason for observing such low $\mathrm{AFB}_{1}$ values is the strict follow-up of aflatoxins from field to storage and from feed production to the animal. In particular, it is thought that the avoiding the use of moldy and low-quality raw materials with is effective in keeping aflatoxin production at low rates. Aflatoxin levels and aflatoxin contamination in animal feedstuffs depend on many factors such as feed composition, feed raw material, storage conditions, geographic area, and seasonal conditions [36].

\subsection{Metal Determination}

The results of the analyses elements concentrations in the compound feed, lamb feed, cattle feed, poultry feed, and feed additive samples are given in Table 4. The European Union and the Republic of Turkey Ministry of Agriculture and Rural Affairs in accordance with the regulations concerning undesirable substances in animal feed, As (in feed materials and complete feed), $\mathrm{Cd}$ (in feed materials and complete feed for cattle, sheep, goat), $\mathrm{Hg}$ (in feed materials and complete feed) and $\mathrm{Pb}$ (in feed materials and complementary feed) limits for $2 \mathrm{mg} / \mathrm{kg}, 1 \mathrm{mg} / \mathrm{kg}, 0.1 \mathrm{mg} / \mathrm{kg}$ and $10 \mathrm{mg} / \mathrm{kg}$ was given $[31,32]$.

Table 4. Element concentrations in animal feed samples $(\mathrm{mg} / \mathrm{kg})$

\begin{tabular}{cccccc}
\hline Element & $\begin{array}{c}\text { Mixed Feed } \\
(\boldsymbol{n}=\mathbf{3 6})\end{array}$ & $\begin{array}{c}\text { Lamb Feed } \\
(\boldsymbol{n}=\mathbf{3})\end{array}$ & $\begin{array}{c}\text { Cattle Feed } \\
(\boldsymbol{n}=\mathbf{1 8})\end{array}$ & $\begin{array}{c}\text { Poultry Feed } \\
(\boldsymbol{n}=\mathbf{6})\end{array}$ & $\begin{array}{c}\text { Feed Additives } \\
(\boldsymbol{n}=\mathbf{1 7})\end{array}$ \\
\hline $\mathrm{Al}$ & $64 \pm 14$ & $48 \pm 2$ & $55 \pm 10$ & $47 \pm 4$ & $61 \pm 16$ \\
$\mathrm{As}$ & $0.11 \pm 0.05$ & $0.092 \pm 0.002$ & $0.12 \pm 0.05$ & $0.063 \pm 0.002$ & $0.11 \pm 0.04$ \\
$\mathrm{Ba}$ & $4.6 \pm 1.9$ & $6.9 \pm 0.1$ & $3.7 \pm 1.1$ & $3.2 \pm 0.7$ & $2.8 \pm 0.9$ \\
$\mathrm{Ca}^{\mathrm{a}}$ & $0.11 \pm 0.04$ & $7.2 \pm 0.2$ & $0.070 \pm 0.014$ & $0.070 \pm 0.007$ & $0.028 \pm 0.006$ \\
$\mathrm{Cd}$ & $0.063 \pm 0.047$ & $0.039 \pm 0.005$ & $0.042 \pm 0.005$ & $0.067 \pm 0.004$ & $0.044 \pm 0.017$ \\
$\mathrm{Co}$ & $0.22 \pm 0.08$ & $0.18 \pm 0.05$ & $0.15 \pm 0.05$ & $0.38 \pm 0.09$ & $0.16 \pm 0.05$ \\
$\mathrm{Cr}$ & $0.48 \pm 0.16$ & $0.35 \pm 0.02$ & $0.35 \pm 0.08$ & $1.3 \pm 0.4$ & $0.37 \pm 0.12$ \\
$\mathrm{Cu}$ & $17 \pm 6$ & $14 \pm 3$ & $15 \pm 4$ & $22 \pm 4$ & $21 \pm 6$ \\
$\mathrm{Fe}^{\mathrm{a}}$ & $0.34 \pm 0.06$ & $0.33 \pm 0.02$ & $0.35 \pm 0.05$ & $0.35 \pm 0.04$ & $0.36 \pm 0.08$ \\
$\mathrm{Hg}$ & $\mathrm{nd} 0.061 \pm 0.001^{\mathrm{c}}$ & $\mathrm{nd}$ & $\mathrm{nd}$ & $\mathrm{nd}$ & $\mathrm{nd} \sim 0.19 \pm 0.09$ \\
$\mathrm{~K}^{\mathrm{a}}$ & $27 \pm 5$ & $23 \pm 1$ & $28 \pm 5$ & $25 \pm 7$ & $48 \pm 9$ \\
$\mathrm{Mg}$ & $3.1 \pm 0.9$ & $3.7 \pm 0.5$ & $3.3 \pm 0.3$ & $1.8 \pm 0.2$ & $4.6 \pm 1.1$ \\
$\mathrm{Mn}$ & $49 \pm 16$ & $85 \pm 2$ & $75 \pm 14$ & $43 \pm 10$ & $40 \pm 7$ \\
$\mathrm{Na}$ & $2.4 \pm 1.2$ & $4.4 \pm 0.3$ & $3.3 \pm 0.8$ & $1.4 \pm 0.1$ & $\mathrm{nd}$ \\
$\mathrm{Ni}$ & $2.7 \pm 0.8$ & $2.6 \pm 0.1$ & $2.8 \pm 0.5$ & $1.9 \pm 0.3$ & $4.1 \pm 1.8$ \\
$\mathrm{P}^{\mathrm{a}}$ & $0.29 \pm 0.06$ & $0.37 \pm 0.02$ & $0.31 \pm 0.04$ & $0.27 \pm 0.05$ & $0.43 \pm 0.12$ \\
$\mathrm{~Pb}$ & $0.047 \pm 0.013$ & $0.18 \pm 0.03$ & $0.085 \pm 0.005$ & $0.060 \pm 0.009$ & $0.050 \pm 0.013$ \\
$\mathrm{Se}$ & $225 \pm 42$ & $252 \pm 11$ & $357 \pm 29$ & $281 \pm 22$ & $224 \pm 29$ \\
$\mathrm{Sn}$ & $\mathrm{nd}$ & $\mathrm{nd}$ & $\mathrm{nd}$ & $\mathrm{nd}$ & $\mathrm{nd}$ \\
$\mathrm{Zn}$ & $61 \pm 15$ & $45 \pm 4$ & $42 \pm 7$ & $92 \pm 6$ & $49 \pm 12$ \\
\hline
\end{tabular}

nd: below the limit of detection

${ }^{\mathrm{a}} \mathrm{g} / 100 \mathrm{~g}$

${ }^{\mathrm{b}}$ mean of two sample

${ }^{\mathrm{c}}$ mean of six sample

The mercury concentrations in two of the samples exceeded the legal limit value of Republic of Turkey Ministry and EU regulations, exceeding $0.1 \mathrm{mg} / \mathrm{kg}$, in this study on feed materials. However, the 
mean mercury concentration determined in six compound feed samples was lower than the legal limits of Turkey Ministry and EU regulations [31,32]. The maximum content of $\mathrm{As}, \mathrm{Cd}$, and $\mathrm{Pb}$ in determined feed samples were found below the legal limits in this study. The contents of elements in different types of animal feed samples has been reported by several authors from different countries. Zhou et al. found the mean concentrations of $\mathrm{Mn}, \mathrm{Fe}, \mathrm{Co}, \mathrm{Ni}, \mathrm{Cu}, \mathrm{Zn}, \mathrm{Se}, \mathrm{Ba}, \mathrm{Al}, \mathrm{Cr}, \mathrm{As}, \mathrm{Cd}, \mathrm{Hg}$, and $\mathrm{Pb}$ 117.96, 664.16, 0.84, $1.18,19.52,98.42,1.50,10.99,492.00,5.23,0.34,0.06,0.01,0.99 \mathrm{mg} / \mathrm{kg}$, respectively [28]. The mean $\mathrm{Mn}, \mathrm{Fe}, \mathrm{Co}, \mathrm{Zn}, \mathrm{Ba}, \mathrm{Al}, \mathrm{Cr}$, and $\mathrm{Pb}$ levels detected in the current study in cattle feed samples are lower than those reported in China by Zhou et al. In this study, the average $\mathrm{Mn}, \mathrm{Co}, \mathrm{Zn}, \mathrm{Ba}, \mathrm{Al}, \mathrm{Cr}$, and $\mathrm{Pb}$ levels in cattle feed samples were found to be lower than those of Zhou et al. In addition, the $\mathrm{Cu}, \mathrm{Se}, \mathrm{As}, \mathrm{Cd}$, and Ni levels were similar to those reported in the studies above [28]. In comparison to the other published work, the results of present study for $\mathrm{Cu}, \mathrm{Fe}$, and $\mathrm{Mg}$ levels showed higher values than Kerr et al [37]. However, other analyzed elements ( $\mathrm{Al}, \mathrm{Ca}, \mathrm{Cd}, \mathrm{Mn}, \mathrm{Ni}$, and $\mathrm{Zn}$ ) were found to be compatible with Kerr et al [37]. When this study was compared with another study in animal feeds, it was found that calcium, copper, iron, manganese, and zinc concentrations were lower in this study [38]. In another study by Pereira et al. on cattle feed, $\mathrm{Co}, \mathrm{Cu}, \mathrm{Mn}$, and $\mathrm{Ni}$ contents were found to be compatible with this study [39].

The relationship between both aflatoxin and element contents in different animal feeds is given in the Table 5. As can be seen from Table 5, the amounts of aflatoxin $\mathrm{B}_{1}$ and $\mathrm{Cd}$ obtained in this study were found to be lower than those obtained from other studies, while the amounts of nickel and selenium were found to be slightly large.

\subsection{Correlation Analysis}

The relationships between the element and aflatoxin toxins ( $\mathrm{AFB}_{1}$ and total $\mathrm{AFs}$ ) concentrations in compound feed samples were evaluated using single correlation analysis. Significant $r$ values $(>| \pm 0.404|, n=24)$ at the $95 \%$ confidence level are represented bold in Table 6 . Table 6 shows that arsenic and selenium elements have a positive correlation with total Aflatoxin and $\mathrm{AFB}_{1}$ in feed samples, and these correlations are also significant $(p<0.05)$. However, the correlation of arsenic with $\mathrm{AFB}_{1}$ and total AFs was found to be very strong compared to that of selenium. Although there is a weak negative correlation between chromium and nickel elements and $\mathrm{AFB}_{1}$ and total $\mathrm{AFs}$, these correlations are not statistically significant.

Although there is a positive correlation between arsenic and selenium contents and $\mathrm{AFB}_{1}$ and total aflatoxin, many factors such as feed composition and type of raw materials used, storage type and conditions, geographical areas and climatic conditions, sampling area, and preparation of samples might be critical factors for findings of toxin content in animal feed samples [36]. In conclusion, these results indicate that samples of animal feed contaminated with total aflatoxin and $\mathrm{AFB}_{1}$ are also contaminated with arsenic and selenium.

\section{Conclusions}

In conclusion, the elements and $\mathrm{AFB}_{1}$ and total $\mathrm{AFs}$ contents were compared using a correlation analysis. A positive correlation was found between arsenic and selenium and $\mathrm{AFB}_{1}$ and total $\mathrm{AFs}$ contents in compound feed samples. Arsenic correlation was significant; but selenium was not significant ( $p<$ 0.05 ). Also, this study underlines the importance of regular monitoring of aflatoxins and element contents in different types of animal feeds in Turkey. To evaluate the main sources of element and aflatoxin contamination, it is necessary to analyze the animal feed materials separately according to their types. Although there is a strong correlation between some elements and aflatoxin contents, some other factors, such as humidity, temperature, and material type that may influence the toxin content in feed samples. Fifty of the total eighty samples analyzed were contaminated with $\mathrm{AFB}_{1}$, and thirty samples were contaminated with $\mathrm{AFB}_{2}$, nine with $\mathrm{AFG}_{1}$, and eight with $\mathrm{AFG}_{2}$. 
Bakırcıglu Kurtuluş et al., J. Chem. Metrol. 15:1 (2021) 52-64

Table 5. Comparison of element and aflatoxin concentration in different types of animal feeds

\begin{tabular}{|c|c|c|c|c|c|c|c|c|c|c|c|c|c|c|c|c|}
\hline $\begin{array}{l}\mathrm{AFB}_{1} \\
\mu \mathrm{g} / \mathrm{kg}\end{array}$ & $\begin{array}{l}\mathrm{AFB} \\
\mu \mathrm{g} / \mathrm{kg}\end{array}$ & $\begin{array}{l}\mathbf{A F G}_{1} \\
\mu \mathrm{g} / \mathrm{kg}\end{array}$ & $\begin{array}{l}\mathbf{A F G}_{2} \\
\mu \mathrm{g} / \mathrm{kg}\end{array}$ & $\begin{array}{l}\Sigma \mathrm{AFs} \\
\mu \mathrm{g} / \mathrm{kg}\end{array}$ & $\begin{array}{c}\mathrm{As} \\
\mathrm{mg} / \mathrm{kg}\end{array}$ & $\begin{array}{c}\mathrm{Cd} \\
\mathrm{mg} / \mathrm{kg}\end{array}$ & $\begin{array}{c}\mathrm{Co} \\
\mathrm{mg} / \mathrm{kg}\end{array}$ & $\begin{array}{c}\mathrm{Cr} \\
\mathrm{mg} / \mathrm{kg}\end{array}$ & $\begin{array}{c}\mathrm{Cu} \\
\mathrm{mg} / \mathrm{kg}\end{array}$ & $\begin{array}{c}\mathrm{Hg} \\
\mathrm{mg} / \mathrm{kg}\end{array}$ & $\begin{array}{c}\mathrm{Ni} \\
\mathrm{mg} / \mathrm{kg}\end{array}$ & $\begin{array}{c}\mathrm{Pb} \\
\mathrm{mg} / \mathrm{kg}\end{array}$ & $\begin{array}{c}\mathrm{Se} \\
\mathrm{mg} / \mathrm{kg}\end{array}$ & $\begin{array}{c}\mathrm{Sn} \\
\mathrm{mg} / \mathrm{kg}\end{array}$ & $\begin{array}{c}\mathrm{Zn} \\
\mathrm{mg} / \mathrm{kg}\end{array}$ & Ref. \\
\hline $15-35$ & $5-25$ & $<0.05-30$ & $<0.03-16$ & $28-90$ & $<$ LOD-3 & $<$ LOD-2.5 & & & & $<$ LOD- 0.444 & & $<$ LOD-4.9 & & & & [36] \\
\hline$<$ LOD-18.4 & & & & $<\mathrm{LOD}$ & & $0.05-0.27$ & & $0.01-16.92$ & & & & $0.39-3.69$ & & $3.26-14.26$ & & [40] \\
\hline & & & & $<0.0005$ & $0.20-0.22$ & $0.11-0.13$ & $0.1-0.6$ & & $\begin{array}{l}13.3- \\
34.1\end{array}$ & $0.03-0.03$ & $0.1-0.6$ & $0.10-0.41$ & $1.4-3.5$ & & $22.4-45.8$ & [41] \\
\hline $0.12-18.12$ & $0.03-1.57$ & $<$ LOD-0.88 & $<$ LOD-1.20 & $0.12-19.70$ & $0.063-0.12$ & $0.039-0.067$ & $0.15-0.38$ & $0.35-1.3$ & $14-22$ & $<$ LOD-0.19 & $1.9-4.1$ & $0.047-0.18$ & $224-357$ & $<$ LOD & $42-92$ & $\begin{array}{l}\text { In this } \\
\text { study }\end{array}$ \\
\hline
\end{tabular}


Aflatoxin and metal concentrations in animal feeds and feed ingredients

Table 6. Correlation coefficients $(r)$ between elements and aflatoxin $\mathrm{B}_{1}$ and total aflatoxins

\begin{tabular}{ccc}
\hline Element & $\mathrm{AFB}_{1}$ & $\mathrm{AFs}$ \\
\hline $\mathrm{Al}$ & -0.001 & -0.001 \\
$\mathrm{As}$ & $\mathbf{0 . 7 6 8}^{\mathbf{a}}$ & $\mathbf{0 . 7 3 3}^{\mathbf{a}}$ \\
$\mathrm{Ba}$ & 0.304 & 0.297 \\
$\mathrm{Ca}$ & 0.052 & 0.055 \\
$\mathrm{Cd}$ & -0.067 & -0.080 \\
$\mathrm{Co}$ & -0.091 & -0.063 \\
$\mathrm{Cr}$ & $\mathbf{- 0 . 4 6 6}$ & $\mathbf{- 0 . 4 0 7}$ \\
$\mathrm{Cu}$ & -0.029 & -0.036 \\
$\mathrm{Fe}$ & 0.119 & 0,075 \\
$\mathrm{~K}$ & 0.114 & 0.111 \\
$\mathrm{Mg}$ & -0.042 & -0.048 \\
$\mathrm{Mn}$ & -0.083 & -0.070 \\
$\mathrm{Na}$ & -0.243 & -0.268 \\
$\mathrm{Ni}$ & $\mathbf{- 0 . 4 1 7}$ & $\mathbf{- 0 . 5 0 3}$ \\
$\mathrm{P}$ & 0.074 & 0.053 \\
$\mathrm{~Pb}$ & 0.131 & 0.090 \\
$\mathrm{Se}$ & $\mathbf{0 . 5 3 5}$ & $\mathbf{0 . 5 2 0}$ \\
$\mathrm{Zn}$ & 0.180 & 0.193 \\
\hline
\end{tabular}

${ }^{\mathrm{a}}$ Correlation is significant at $95 \%$ confidence level $\left(r_{\text {critical }}=\mathbf{0 . 4 0 4}, n=24\right.$

\section{Acknowledgements}

The authors would like to thank the Unit of the Scientific Research of Trakya University (TUBAP-2010-177) for providing financial support.

\section{ORCID}

Yasemin Bakircioglu Kurtulus: 0000-0003-3013-5793

Dilek Bakircioglu: 0000-0003-3384-0340

Muhammet Kuscu: 0000-0002-1503-3716

Nukte Topraksever:0000-0001-8982-2219

Orhan Destanoglu: 0000-0003-2477-0694

\section{References}

[1] G. Jard, T. Liboz, F. Mathieu, A. Guyonvarch and A. Lebrih (2011). Review of mycotoxin reduction in food and feed: from prevention in the field to detoxification by adsorption or transformation, Food Addit. Contam. A 28 (11), 15901609.

[2] World Health Organization (WHO) (2002). Safety evaluation of certain mycotoxins in food. Fifty-sixth report of the Joint FAO/WHO Expert Committee on Food Additives, WHO Technical Report Series 906. Geneva.

[3] A. Ehsani, A. Barani and Z. Nasiri (2016). Occurrence of aflatoxin B1 contamination in dairy cows feed in Iran, Toxin Rev. 35 (1-2), 54-57.

[4] H.N. Mishra and C. Das (2003). A Review on Biological Control and Metabolism of Aflatoxin, Crit. Rev. Food Sci. Nutr. 43 (3), 245-264.

[5] Y.-H. Leong, N. Ismail, A.A. Latif and R. Ahmad (2010). Aflatoxin occurrence in nuts and commercial nutty products in Malaysia, Food Cont.21, 334-338.

[6] W.F. Jaynes, R.E. Zartman and W.H. Hudnall (2007). Aflatoxin B1adsorption by clays from water and corn meal, Appl. Clay Sci. 36, 197-205.

[7] N. Unusan (2019). Systematic review of mycotoxins in food and feeds in Turkey, Food Cont. 97, 1-14.

[8] N.I. Tahir, S. Hussain, M. Javed, H. Rehman, T.G. Shahzady, B. Parveen and K. G. Ali (2018). Nature of aflatoxins: Their extraction, analysis, and control, J. Food Saf. 38(6), e12561.1-7 
Bakırcıglu Kurtuluş et al., J. Chem. Metrol. 15:1 (2021) 52-64

[9] International Agency for Research on Cancer (IARC) (2002). Working Group on the Evaluation of Carcinogenic Risks to Humans. Some traditional herbal medicines, some mycotoxins, naphthalene and styrene, IARC Monogr. Eval. Carcinog. Risks Hum. 82, 1-556.

[10] F.A. Azri, J. Selamat and R. Sukor (2017). Electrochemical immunosensor for the detection of aflatoxin B1in palm kernel cake and feed samples, Sensors 17(2), 2776, (11 pages).

[11] G.S. Shephard (2009). Aflatoxin analysis at the beginning of the twenty-first century, Anal. Bioanal. Chem. 395, 12151224 .

[12] F. Berthiller, B. Cramer, M.H. Iha, R. Krska, V.M.T. Lattanzio, S. MacDonald, R.J. Malone, C. Maragos, M. Solfrizzo, M. Stranska-Zachariasova, J. Stroka and S. A. Tittlemier (2018). Developments in mycotoxin analysis: an update for 2016-2017. World Mycotoxin J. 11(1), 5-32.

[13] J. Yang, J. Li, Y. Jiang, X. Duan, H. Qu, B. Yang, F. Chen and D. Sivakumar (2014). Natural occurrence, analysis, and prevention of mycotoxins in fruits and their processed products, Crit. Rev. Food Sci. Nutr. 54, 64-83.

[14] F. Sakin, I.O. Tekeli, M. Yipel and C. Kurekci (2018). Occurrence and health risk assessment of aflatoxins and ochratoxin a in Sürk, a Turkish dairy food, as studied by HPL, Food Cont. 90, 317-323.

[15] G. Kos, M. Sieger, D. McMullin, C. Zahradnik, M. Sulyok, T. Oner, B. Mizaikoff and R. Krska (2016). A novel chemometric classification for FTIR spectra of mycotoxin-contaminated maize and peanuts at regulatory limits, Food Addit. Contam. A 33(10), 1596-1607.

[16] G.K. Blankson, F.C. Mills-Robertson and I.W Ofosu (2019). Survey of occurrence levels of aflatoxins in selected locally processed cereal-based foods for human consumption from Ghana, Food Cont. 95, 170-175.

[17] S. Somsubsin, K. Seebunrueng, S. Boonchiangma and S. Srijaranai (2018). A simple solvent based microextraction for high performance liquid chromatographic analysis of aflatoxins in rice samples, Talanta 176, 172-177.

[18] N.A. Alkhalaf, K. Osman and A. Salama (2010). Monitoring of aflatoxins and heavy metals in some poultry feeds, Afr. J. Food Sci. 4(4), 192-199.

[19] D. Bakircioglu, Y.B. Kurtulus and H. Ibar (2011). Comparison of extraction procedures for assessing soil metal bioavailability of to wheat grains, Clean - Soil, Air, Water 39(8), 728-734.

[20] M.H. Hinton (2000). Infections and intoxications associated with animal feed and forage which may present a hazard to human health, Vet. J. 159(2), 124-138.

[21] T.G. Kazi, A.Q. Shah, H.I. Afridi, N.A. Shah and M.B. Arain (2013). Hazardous impact of organic arsenical compounds in chicken feed on different tissues of broiler chicken and manure, Ecotoxicol. Environ. Saf. 87, 120-123.

[22] M. Hejna, D. Gottardo, A. Baldi, V. Dell'Orto, F. Cheli, M. Zaninelli and L. Rossi (2018). Review: Nutritional ecology of heavy metals, Animal 12(10), 2156-2170.

[23] S.A. Mahesar, S.T.H. Sherazi, A. Niaz, M.I. Bhanger, S. Uddin and A. Rauf (2010). Simultaneous assessment of zinc, cadmium, lead and copper in poultry feeds by differential pulse anodic stripping voltammetry, Food Chem. Toxicol. 48 (8-9), 2357-2360.

[24] A. Mehri and R. F. Marjan (2013). Trace elements in human nutrition : A eeview, Int. J. Med. Invest. 2 (3), 115-128.

[25] W. Li, P. Simmons, D. Shrader, T.J. Herrman and S.H. Dai (2013). Microwave plasma-atomic emission spectroscopy as a tool for the determination of copper, iron, manganese and zinc in animal feed and fertilizer, Talanta 112, 43-48.

[26] D.V.L. Avila, A.R. Borges, M.G.R. Vale, R.G.O. Araujo and E.A. Passos (2017). Determination of Co and Cr in wet animal feeds using direct solid sample analysis by HR-CS GF AAS, Microchem. J. 133, 524-529.

[27] D. Bakircioglu, N. Topraksever, S. Yurtsever, M. Kizildere and Y.B. Kurtulus (2018). Investigation of macro, micro and toxic element concentrations of milk and fermented milks products by using an inductively coupled plasma optical emission spectrometer, to improve food safety in Turkey, Microchem. J. 136, 133-138.

[28] X. Zhou, X., Qu, S. Zhao, J. Wang, S. Li and N. Zheng (2017). Analysis of 22 Elements in Milk, Feed, and Water of Dairy Cow, Goat, and Buffalo from Different Regions of China, Biol. Trace Elem. Res. 176, 120-129.

[29] D. Mendil, Z. Demirci, M. Tuzen and M. Soylak (2010). Seasonal investigation of trace element contents in commercially valuable fish species from the Black sea, Food Chem. Toxicol.48 (3), 865-870.

[30] Association of Official Analytical Chemists Method (AOAC) (2005). Natural toxins. Aflatoxins. Gaithersburg (MD): $J$. AOAC Int. 49, 38

[31] European Commission, Commission Regulation (EC) (2002). No 2002/32/EC of the European Parliament and of the Council of 7 May 2002. Undesirable substance in animal feed, Offical J. Eur. Union L 140.

[32] Turkish Food Codex (TFC), (2005). Turkey Ministry of Agriculture and Rural Affairs: Communiqué on unwanted substances in feed. Communiqué No: 2005/3, Official Gazette, Issue: 25718.

[33] European Commission, Commission Regulation (EC) (2006). No 1881/2006, Setting maximum levels for certain contaminants in foodstuffs, Off. J. Eur. Union, L 364/5.

[34] Turkish Food Codex (TFC) (2011). Turkey Ministry of Agriculture and Rural Affairs: The maximum allowed level of food contaminants. Offical Gazette No. 28157.

[35] Codex Alimentarius Commission (CAC) (1997). Code of practice for the reduction of aflatoxin B1 in raw materials and supplemental feedingstuffs for milk and milk producing animals. CAC/RCP 45-1997. Food and Agriculture Organization, Rome, Italy.

[36] M.H. Eskandari and S. Pakfetrat (2014). Aflatoxins and heavy metals in animal feed in Iran, Food Addit. Contam. Part B Surveill. 7(3), 202-207. 
[37] B.J. Kerr, C.J. Ziemer, T.E. Weber, S.L. Trabue, B.L. Bearson, G.C. Shurson and M.H. Whitney (2008). Comparative sulfur analysis using thermal combustion or inductively coupled plasma methodology and mineral composition of common livestock feedstuffs, J. Anim. Sci. 86 (9), 2377-2384.

[38] J.F. Liu, Y.D. Feng and G.B. Jiang (2001). Identical flow injection spectrophotometric manifold for determination of protein, phosphorus, calcium, chloride, copper, manganese, iron, and zinc in feeds or premixes, J. AOAC Int. 84 (4), 1179-1186.

[39] V. Pereira, P. Carbajales, M. Lopez-Alonso and M. Miranda (2018). Trace element concentrations in beef cattle related to the breed aptitude, Biol. Trace Elem. Res. 186 (1), 135-142.

[40] Y.M. Abd-Elhakim, N.I. El Sharkawy and G.G. Moustafa (2016). An investigation of selected chemical contaminants in commercial pet foods in Egypt, J. Vet. Diagn. Investig. 28 (1),70-75.

[41] E.S.M. Abdel-Aal, P. Hucl, C. A. Patterson and D. Gray (2011). Phytochemicals and heavy metals content of hairless canary seed:A variety developed for food use, LWT - Food Sci. Technol. 44, 904-991.

$$
\underset{\substack{\text { publications } \\ \text { C) } 2021 \text { ACG Publications }}}{\mathrm{C}}
$$

